\title{
PHYSICAL AND FUNCTIONAL EVALUATION OF EXTRUDED FLOURS OBTAINED FROM DIFFERENT RICE GENOTYPES
}

\author{
Avaliação física e funcional de farinhas extrudadas \\ obtidas de diferentes genótipos de arroz
}

\author{
Fernanda Salamoni Becker ${ }^{1}$, Eduardo da Costa Eifert ${ }^{2}$, Manoel Soares Soares Junior ${ }^{3}$, \\ July-Ana Souza Tavares ${ }^{4}$, Ana Vânia Carvalho ${ }^{5}$
}

\begin{abstract}
The transformation of broken grains into native flours modified by extrusion is an alternative to add value to these co-products from the paddy rice processing. This study aimed to analyze the process of extrusion cooking on the physical and functional characteristics of extruded flours obtained from different rice genotypes (IRGA-417, BRS-Primavera and CNA-8502). The experimental design was completely randomized ( $3 \times 2$ factorial) with four original replicates and analysis of variance to assess particle size, instrumental color parameters ( $\mathrm{L}^{*}, \mathrm{a}^{*}$ and $\mathrm{b}^{*}$ ), water absorption index (WAI), milk absorption index (MAI), oil absorption index (OAI), water solubility index (WSI) and milk solubility index (MSI) of rice flour. The extrusion process promoted changes in all physical and functional properties of rice flour, but only WSI and color parameters were influenced by genotype and by the industrial processing. Rice flours become darker, tending to a more reddish and yellow coloration after extrusion. Native and extruded rice flours of genotypes IRGA-417, BRS-Primavera and extruded rice flour of genotype CNA-8502 showed finer particles, while native flour of genotype CNA-8502 showed coarser particles. The extruded flours of IRGA-417 genotype obtained higher expansion and luminosity, and lower values of chroma $a^{*}$, chroma b* and water solubility, while the BRS-Primavera higher values of chroma $\mathrm{a}^{*}$ and $\mathrm{b}^{*}$, and lower luminosity and expansion, and CAN-8502 higher water solubility and lower expansion and value of chroma $\mathrm{a}^{*}$. The extrusion process led to flours with high water and milk absorption and solubility, low oil absorption and with potential for application in instant products, regardless of genotype.
\end{abstract}

Index terms: Orysa sativa L., co-products, electron microscopy, color, solubility in water.

\section{RESUMO}

A transformação de grãos quebrados em farinhas nativas e modificadas por extrusão é uma alternativa para agregar valor a esses coprodutos do beneficiamento do arroz em casca. Neste estudo, objetivou-se avaliar o processo de extrusão sobre as propriedades físicas e funcionais de farinhas obtidas de diferentes genótipos de arroz (IRGA-417, BRS-Primavera e CNA-8502). Utilizou-se delineamento experimental inteiramente casualizado, tipo fatorial $3 \times 2$, com quatro repetições originais, e análise de variância para avaliar a granulometria, os parâmetros instrumentais de cor (L*, $\mathrm{a}^{*}$ e b*), os índices de absorção de água (IAA), leite (IAL) e óleo (IAO), e a solubilidade em água (ISA) e em leite (ISL) das farinhas de arroz. A extrusão promoveu alterações em todas as propriedades físicas e funcionais da farinha de arroz, mas somente o ISA e os parâmetros de cor foram influenciados pelo genótipo e pelo tratamento industrial. As farinhas de arroz tornaram-se mais escuras, tendendo para uma coloração mais avermelhada e amarela após a extrusão. As farinhas de arroz nativas e extrusadas dos cvs. IRGA-417 e BRS-Primavera, e a farinha de arroz extrusada do genótipo CNA-8502 apresentaram partículas mais finas, enquanto que a farinha nativa da linhagem CNA-8502 apresentou partículas mais grossas. As farinhas extrusadas do genótipo IRGA-417 obtiveram maiores expansão e luminosidade, e menores valores de croma a *, croma b * e solubilidade em água, enquanto que as da BRSPrimavera obtiveram maiores valores de croma a* e b*, e menores luminosidade e expansão, e as da CNA-8502, maior solubilidade em água e menores expansão e valor de croma a*. A partir da extrusão, é possível obter farinhas extrusadas com alta absorção e solubilidade em água e leite, baixa absorção em óleo, apresentando potencial para aplicação em produtos instantâneos, independente do seu genótipo.

Termos para indexação: Orysa sativa L., co-produtos, microscopia eletrônica, cor, solubilidade em água.

\section{INTRODUCTION}

During paddy rice processing, brown rice, full parboiled, polished and polished parboiled rice are obtained, besides hulls, bran, broken grains and grits. Given the global and domestic paddy rice production and the percentage of broken grains and grits $(\approx 14 \%)$ (Bassinello; Castro, 2004), the estimated world generation of these co-products in 2012 was around 102.70 million tons, of these, 1,654.76 thousand tons were generated in Brazil.

The products formulation, having rice as a raw material, is unfeasible due to the market value

\footnotetext{
${ }^{1}$ Universidade Federal de Goiás/UFG - Campus Samambaia - Cx. P. 131 - 74690-900 - Goiânia - GO - Brasil - fsb.fernanda@hotmail.com Empresa Brasileira de Pesquisa Agropecuária/EMBRAPA - Santo Antônio de Goiás - GO - Brasil

3Universidade Federal de Goiás/UFG - Escola de Agronomia e Engenharia de Alimentos - Goiânia - GO - Brasil

${ }^{4}$ Universidade Federal de Goiás/UFG - Goiânia - GO - Brasil

${ }^{5}$ Empresa Brasileira de Pesquisa Agropecuária/EMBRAPA - Amazônia Oriental - Belém - PA - Brasil

Received in may 07, 2014 and approved in july 02, 2014
}

Ciênc. Agrotec., Lavras, v.38, n.4, p.367-374, jul./ago., 2014 
that the product achieves in the form of whole grains (Nabeshima; El-Dash, 2004). However, the use of broken grain and grits in the form of flour is an alternative for the transformation of these co-products into products of greater commercial and industrial interest, since they have low commercial value, achieving about $20 \%$ of the value paid for whole-grain rice. Broken grains are primarily intended for use in breweries and wineries as adjuvant in the fermentation process and in the animal feed industry (Limberger et al., 2008). On the other hand, rice flour is also used in the production of instant foods, meat products, baby foods, porridge-type products for children, creams and powder for desserts, among others (Nabeshima; El-Dash, 2004). Rice flour has advantages such as not being allergenic, gluten-free, containing low glycemic index, low sodium contents and high proportion of easily digestible starches (Kadan; Bryant; Pepperman, 2003).

Rice cultivars IRGA-417 and BRS-Primavera are the main genetic materials used in the production of irrigated and high-land rice, respectively. While these cultivars have average cooking time of $10 \mathrm{~min}$, resulting in soft and slightly loose grains, genotype CNA-8502 has longer cooking time (26 min) with soft and slightly sticky grains, which exemplifies the chemical and technological differences between different genetic rice materials.

Thermoplastic extrusion is a process which combines several unit operations such as mixing, cooking, kneading, shearing, forming and molding (Fellows, 2009). This process has provided numerous applications in the food industry, such as the development of instant products with cereals, legumes, roots and tubers such as breakfast cereals, snacks, pasta, fortified foods, powdered beverages, textured soy protein, sauces, confectionery products, flours and pre-gelatinized starches used in the formulation of instant soups, among others (Cheyne; Barnes;Wilson, 2005). This study aimed to analyze the process of extrusion cooking on the physical and functional characteristics of extruded flours obtained from different rice genotypes (IRGA-417, BRS-Primavera and CNA-8502).

\section{MATERIAL AND METHODS}

\section{Raw material}

Broken rice grains (2009 harvest) of genotypes IRGA-417, BRS-Primavera and CNA-8502 were used, the first genotype coming from the state of Rio Grande do Sul and the others from the Embrapa Arroz e Feijão rice improvement program, Santo Antonio de Goiás, GO.

\section{Production of native and pre-gelatinized flours}

Broken rice grains of three genotypes were ground in a Wiley-type mill (Perten, Laboratory Mill 3100, Mainland, China) to obtain native rice flours (NRF), which were homogenized, $5 \mathrm{~kg}$ of each sample was placed in low density polyethylene (LDPE) container and stored at room temperature until time of analysis. Half of NRF obtained from each genotype was subjected to extrusion processing. For that, they were conditioned to $17{\mathrm{~g} 100 \mathrm{~g}^{-1}}^{-1}$ moisture by spraying distilled water with hand spray and stored in LDPE packages at temperature of $7 \pm 1^{\circ} \mathrm{C}$ for 24 hours until moisture homogenization. The process of thermoplastic extrusion was applied in the single-screw extruder (Inbramaq, RXPQ Labor 24, Ribeirão Preto, Brazil), with parameters: helical jacket, thread of $300 \mathrm{~mm}$ in length with compression rate of $3: 1$, circular array of $3.85 \mathrm{~mm}$; temperature in $1^{\text {st }}, 2^{\text {nd }}$ and $3^{\text {rd }}$ heating zone respectively of 40,60 and $80^{\circ} \mathrm{C}$; feed rate of $218 \mathrm{~g} \mathrm{~min}^{-1}$ and screw speed of 180rpm. Extruded rice flour (ERF) was obtained by grinding in Wiley-type mill (Perten, Laboratory Mill 3100, Mainland, China), packed in LDPE containers and stored at room temperature until time of analysis. NRF and ERF were sieved through stainless steel 60 mesh sieve, using the passing portions for analyses.

\section{Expansion index}

The expansion index (EI) of extruded rice flour was obtained immediately after extrusion and calculated by the ratio between the diameter of extruded and the diameter of the matrix $(3.85 \mathrm{~mm})$. The diameter was measured using a caliper, and values were obtained by the arithmetic mean of 20 different extruded randomly chosen for each genotype.

\section{Particle size of flours}

The particles size were certain by method of the Association of Official Analytical Chemists - AOAC (2010) using a set of sieves of 48, 60, 80, 100, 150, 200 mesh and background with masses previously separated with sieve shaker (Artlab, Produtest 2431, Engenho Novo, Brazil).

\section{Scanning electron microscopy}

The NRF and ERF morphology was analyzed using scanning electron microscope (Zeiss DSM 940A, Oberkochen, Federal Republic of Germany), with 2000 $\mathrm{X}$ magnification. The flours were diluted in ethyl alcohol

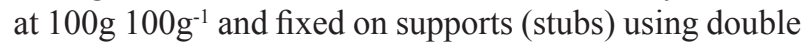
sided adhesive tape. After fixation, the flour was covered with a thin layer of gold sputter coating (Balzers) and assessed under voltage of 20KVA. 


\section{Color Instrumental parameters}

Instrumental color parameters were measured in Hunter Lab colorimeter (Color Quest XE, Reston, USA), using observation angle of $10^{\circ}$ and illuminant $\mathrm{D}_{65}$. The results were expressed using the CIE $\mathrm{L}^{*} \mathrm{a}^{*} \mathrm{~b}^{*}$ system, where $L^{*}$ values range from black $(0)$ to white $(100)$, $a^{*}$ values range from green $(-60)$ to red $(+60)$, and $b^{*}$ values range from blue $(-60)$ to yellow $(+60)$.

\section{Absorption and solubility}

Water absorption index (WAI), milk absorption index (MAI) and oil absorption index (OAI), as well as water solubility index (WSI) and milk solubility index (MSI) were determined according to methodology described by Anderson et al. (1969), with modifications for OAI and MAI, in which distilled water was replaced by oil and milk, respectively, and for MSI, in which the soluble solids of flour were determined in milk. All analyses were performed in triplicate.

\section{Statistical Analysis}

The NRF and ERF of the three genetic materials were evaluated using evaluated using completely randomized design with $3 \times 2$ factorial arrangement and four original replicates. Data were submitted to analysis of variance (ANOVA) and means were compared by the Tukey test at 5\% probability using the Statistical Analisys System - SAS for Windows software, version 8.1 (SAS, 2003).

\section{RESULTS AND DISCUSSION}

\section{Expansion}

The EI was higher in extruded flour of cultivar IRGA417 (3.14 \pm 0.17$)$, which was statistically different $(\mathrm{p} \leq 0.05)$ from cultivar CNA-8502 (2.93 \pm 0.08$)$ and BRS-Primavera
$(2.90 \pm 0.21)$, which did not differ from one another $(\mathrm{p}>$ 0.05). According to Becker et al. (2013), NRF cultivar BRS Primavera and CNA-8502 showed protein $(8.90$ and $10.23 \mathrm{~g}$

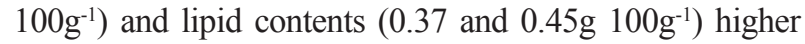
than those found for NRF cultivar IRGA 417 (8.52 and

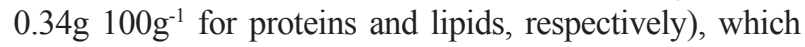
explains its lower EI in relation to others. Proteins affect expansion by adjusting water distribution in the feed matrix and contributing to extensive networking through covalent and nonbonding interactions that take place during extrusion (Day; Swanson, 2013). Oils and fats have lubricating action, which reduces the dissipation of mechanical energy and protects the dispersion of the starch granule during extrusion. This also reduces the amount of starch gelatinized in the mass and reduces the expansion of extrudates (Guy, 2001). The production of characteristic textures is one of the main aspects of extrusion technology. The degree of modification of starch, determined by the extrusion conditions and characteristics of the raw material, produces a wide variety of textures, or products with different degrees of expansion (Fellows, 2009), with wide application in snack foods and breakfast cereals.

\section{Coloring}

All instrumental color parameters were affected by the extrusion process, with significant interaction between genotype and industrial treatment (Table 1). It was observed that ERF cultivar BRS Primavera was the rice cultivar that most changed its color with the extrusion process, from the highest $\mathrm{L}^{*}$ value to the lowest value ( $7.6 \%$ reduction) and from the lowest $\mathrm{a}^{*}$ and $\mathrm{b}^{*}$ values to the highest values $(630 \%$ and $256.2 \%$ increase), respectively. During the extrusion process, there were reactions that changed the color of the extrudate, and the most common were non- enzymatic

Table 1 - Lightness $\left(\mathrm{L}^{*}\right)$ and chroma $\mathrm{a}^{*}$ and $\mathrm{b}^{*}$ of native (NRF) and extruded rice flour (ERF) of genotypes IRGA-417 (G1), BRS-Primavera (G2) and CNA-8502 (G3).

\begin{tabular}{lcccc}
\hline \multirow{2}{*}{ Parameter 2 } & Treatment & \multicolumn{3}{c}{ Genotype $^{1}$} \\
\cline { 3 - 5 } & & G1 & G2 & G3 \\
\hline \multirow{2}{*}{ Lightness $\left(L^{*}\right)$} & NRF & $92.49 \pm 0.13^{\mathrm{ABa}}$ & $92.64 \pm 0.15^{\mathrm{Aa}}$ & $92.37 \pm 0.10^{\mathrm{Ba}}$ \\
& ERF & $86.62 \pm 0.11^{\mathrm{Aa}}$ & $85.80 \pm 0.11^{\mathrm{Cb}}$ & $86.09 \pm 0.08^{\mathrm{Bb}}$ \\
Chroma a* $^{*}$ & NRF & $-0.22 \pm 0.01^{\mathrm{Ab}}$ & $-0.30 \pm 0.02^{\mathrm{Bb}}$ & $-0.29 \pm 0.01^{\mathrm{Bb}}$ \\
& ERF & $0.64 \pm 0.02^{\mathrm{Ba}}$ & $1.19 \pm 0.02^{\mathrm{Aa}}$ & $0.67 \pm 0.01^{\mathrm{Ba}}$ \\
Chroma b* $^{*}$ & NRF & $5.06 \pm 0.01^{\mathrm{Bb}}$ & $4.50 \pm 0.03^{\mathrm{Cb}}$ & $5.20 \pm 0.02^{\mathrm{Ab}}$ \\
\hline
\end{tabular}

${ }^{1}$ Mean values ollowed by standard deviations; ${ }^{2}$ different uppercase letters (same row) and lowercase (same column) differed by the Tukey test at $5 \%$ probability. 
browning reactions such as Maillard and caramelization reactions and degradation of pigments, in which the lightness value decreases, while chromaticity coordinates $\mathrm{a}^{*}$ and $\mathrm{b} *$ values increase (Ilo; Berghofer, 1999), which phenomena were observed in the ERF of the present study. Coutinho et al. (2013) studying the extrusion conditions in order to obtain snacks from by-products of rice and soybean (90:10) with physical characteristics appropriate for marketing, obtained higher values of luminosity $(86,8-86,6)$, lower of chroma $a^{*}$ and similar of chroma $b^{*}$ than the values obtained in the present work, due to the higher amount of dark pigment present in the coat of black soybean.

\section{Particle size}

There was significant variation in the particle size of each genotype in relation to industrial processing, with the exception of rice flour cultivar IRGA-417 in the particle size range from 80 to $150 \mu \mathrm{m}$, and cultivar BRS-Primavera in the range from 150 to $180 \mu \mathrm{m}$.

The ERF of genotypes IRGA-417 and CNA-8502 showed greater particle retention than NRF in finer sieves, while in higher mesh size, the opposite was observed (Table $2)$. ERF showed mostly fine particles $(<250 \mu \mathrm{m})$, which reflects the increased friability of the extruded material compared to the native material. NRF starch granules have harder crystalline structure, while the extruded material has amorphous structure (less hard) (Borba, Sarmento; Leonel, 2005). NRF cultivar IRGA-417, 80 $100 \mathrm{~g}^{-1}$ particles were between 80 and $250 \mathrm{~mm}$, for NRF cultivar BRSPrimavera, $76.9 \mathrm{~g} 100 \mathrm{~g}^{-1}$ between 74 and $180 \mathrm{~mm}$, and for NRF cultivar CNA-8502, 76.8g $100 \mathrm{~g}^{-1}$ between 150 and $250 \mathrm{~mm}$. Therefore, among NRFs, genotype CNA-8502 showed greater uniformity due to its higher protein content (uniformly distributed in the endosperm) and less ash (concentrated in the bran fraction), compared to the other materials (Bassinello; Castro, 2004; Becker et al., 2013). For extrusion, the particle size is an important factor. Smaller particles are quickly melted and the resulting low-viscosity mass is not properly conveyed through the extruder screw, which can even cause the burning of the material inside the extruder (Mendonça et al., 2005).

\section{Morphology}

In all NRFs, the structures of particle components are visible in some areas, being clustered in some areas and with smooth surface in other areas (Figure 1). Starch granules are identified by micrographs, showing irregular

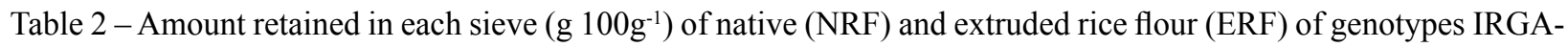
417 (G1), BRS-Primavera (G2) and CNA-8502 (G3).

\begin{tabular}{|c|c|c|c|c|}
\hline \multirow{2}{*}{$\begin{array}{l}\text { Particle size } \\
\qquad(\mathrm{mm})\end{array}$} & \multirow{2}{*}{ Treatment } & \multicolumn{3}{|c|}{ Genotype $^{1}$} \\
\hline & & G1 & $\mathrm{G} 2$ & G3 \\
\hline \multirow{2}{*}{$>297^{2}$} & NRF & $2.29 \pm 0.16^{\mathrm{a}}$ & $2.05 \pm 0.13^{\mathrm{a}}$ & $2.87 \pm 0.22^{\mathrm{a}}$ \\
\hline & ERF & $0.39 \pm 0.01^{\mathrm{b}}$ & $0.33 \pm 0.02^{\mathrm{b}}$ & $0.38 \pm 0.03^{b}$ \\
\hline \multirow{2}{*}{$250-297$} & NRF & $4.82 \pm 0.18^{\mathrm{a}}$ & $2.22 \pm 0.08^{b}$ & $10.78 \pm 0.67^{\mathrm{a}}$ \\
\hline & ERF & $2.84 \pm 0.18^{b}$ & $2.51 \pm 0.06^{\mathrm{a}}$ & $3.50 \pm 0.06^{\mathrm{b}}$ \\
\hline \multirow{2}{*}{$180-250$} & NRF & $24.29 \pm 1.05^{\mathrm{a}}$ & $8.20 \pm 0.45^{\mathrm{b}}$ & $48.53 \pm 1.58^{\mathrm{a}}$ \\
\hline & ERF & $16.20 \pm 0.52^{\mathrm{b}}$ & $14.91 \pm 0.31^{\mathrm{a}}$ & $16.76 \pm 0.09^{b}$ \\
\hline \multirow{2}{*}{$150-180$} & NRF & $28.51 \pm 1.42^{\mathrm{a}}$ & $15.50 \pm 1.14^{\mathrm{a}}$ & $28.24 \pm 1.75^{\mathrm{a}}$ \\
\hline & ERF & $15.61 \pm 0.22^{\mathrm{b}}$ & $14.57 \pm 0.27^{\mathrm{a}}$ & $15.06 \pm 0.08^{b}$ \\
\hline \multirow{2}{*}{$80-150$} & NRF & $27.20 \pm 1.28^{\mathrm{a}}$ & $33.44 \pm 0.95^{\mathrm{a}}$ & $7.01 \pm 0.25^{b}$ \\
\hline & ERF & $25.89 \pm 0.03^{\mathrm{a}}$ & $24.39 \pm 0.68^{\mathrm{b}}$ & $24.30 \pm 0.09^{\mathrm{a}}$ \\
\hline \multirow{2}{*}{$74-80$} & NRF & $10.21 \pm 0.62^{\mathrm{b}}$ & $27.95 \pm 0.78^{a}$ & $2.30 \pm 0.09^{\mathrm{b}}$ \\
\hline & ERF & $18.42 \pm 0.42^{\mathrm{a}}$ & $19.18 \pm 0.30^{b}$ & $18.25 \pm 0.32^{\mathrm{a}}$ \\
\hline \multirow{2}{*}{$<74$} & NRF & $2.68 \pm 0.16^{\mathrm{b}}$ & $10.67 \pm 0.43^{\mathrm{b}}$ & $0.28 \pm 0.02^{\mathrm{b}}$ \\
\hline & ERF & $20.65 \pm 0.69^{\mathrm{a}}$ & $24.12 \pm 0.95^{\mathrm{a}}$ & $21.76 \pm 0.35^{\mathrm{a}}$ \\
\hline
\end{tabular}

${ }^{1}$ Mean values followed by standard deviations, ${ }^{2}$ different letters on the same column on each sieve differ significantly by the Tukey test at $5 \%$ probability.

Ciênc. Agrotec., Lavras, v.38, n.4, p.367-374, jul./ago., 2014 
shapes, probably caused by their spatial arrangement and their more or less compressed arrangement in the grain endosperm.

NRF of genotype BRS-Primavera showed a more dense and compacted structure, whereas NRF of genotypes IRGA-417 and CNA-8502 showed more porous structure. It is assumed that more porous and less dense particles have the property of causing damping effect, which reduces the impact of the equipment knives, reducing the milling efficiency and resulting in flour with coarser particle size. Thus, higher density of particles of the NRF (BRS-Primavera) facilitated the rupture of the starch endosperm structure, yielding a thinner particle size (Table 2).

ERF showed amorphous and compact structure, with irregular surface, smooth or ribbed parts and some holes, and did not enable distinguishing starch granules from other components or structures (Figure 2). During the NRF melting, there was formation of complexes among the endosperm components such as starch granules, proteins, and other components, resulting in a more homogeneous product (ERF). An alignment of particles in the longitudinal direction was also observed, caused by the continuous flow and output of the material through the die during melting of material extruded (Fellows, 2009). The holes are the result of the formation of vapor bubbles that permeate the material by leaving the extruder due to the expansion of extruded starchy materials that occurs during product decompression (steam jets).

\section{Water and milk absorption indexes}

Only industrial treatment (NRF / ERF) had a significant effect on the WAI (Table 3). WAI varies with the gelatinization degree of starch during the extrusion process, so the higher the gelatinization degree, the greater the number of available hydroxyl groups to form hydrogen bonds with water and, consequently, the greater the WAI (Clerici; El-Dash, 2008).

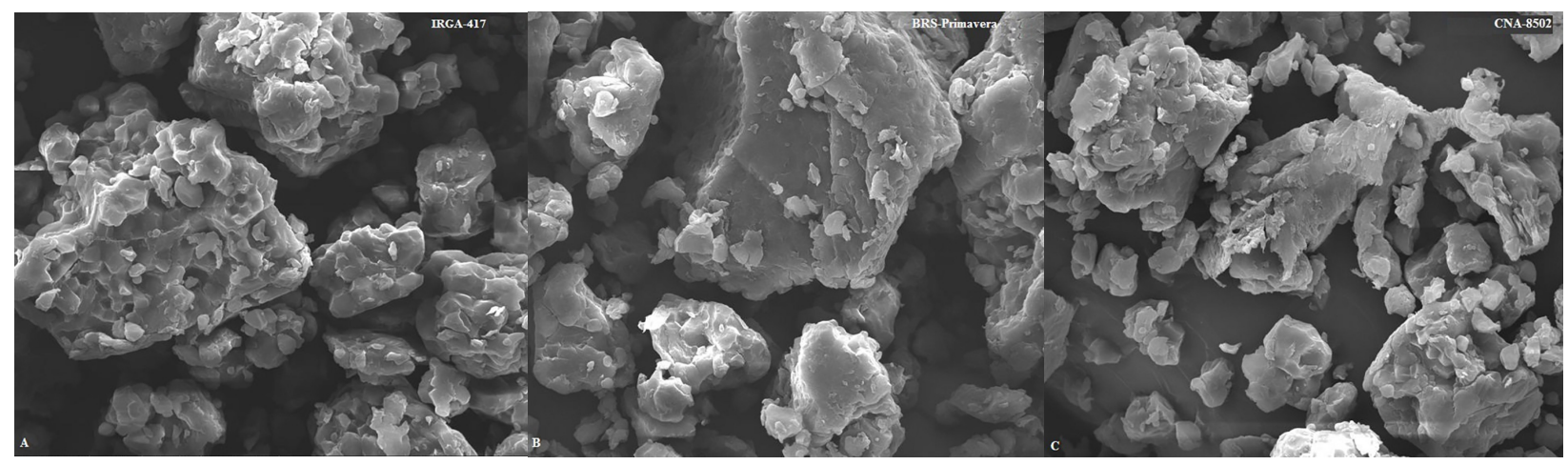

Figure 1 - Scanning electron micrographs under $2000 \mathrm{X}$ magnification of native rice flours (NRF): A: IRGA-417, B: BRS-Primavera and C: CNA-8502.

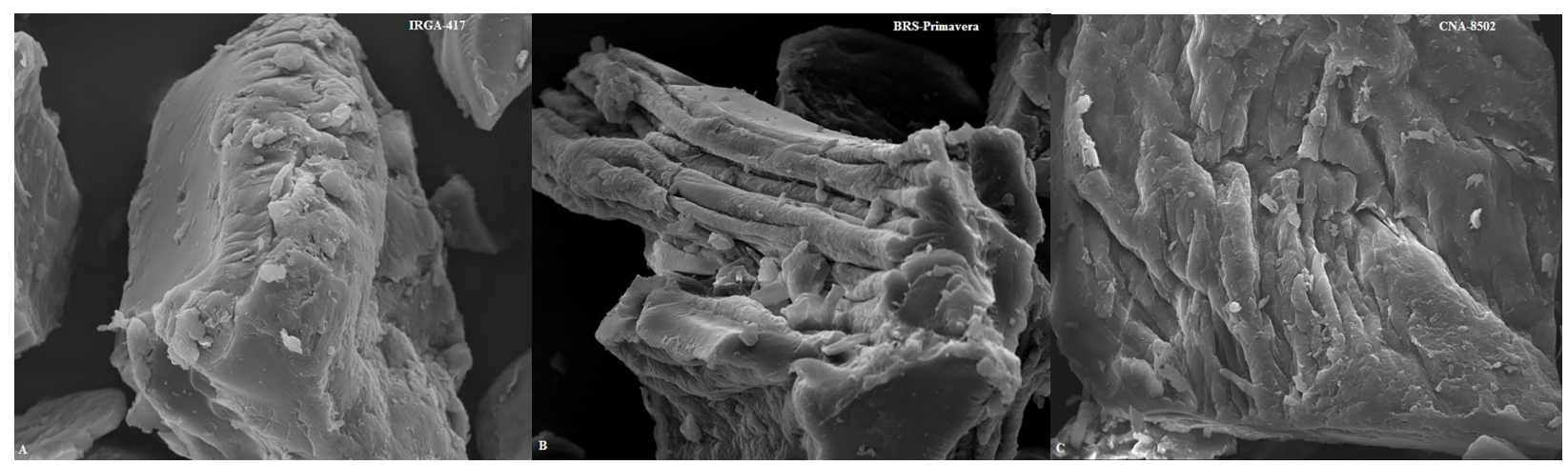

Figure 2 - Scanning electron micrographs under 2000x magnification of extruded rice flours (ERF): A: IRGA-417, B: BRS-Primavera and C: CNA-8502. 
Table 3 - Functional properties ${ }^{1}$ of native (NRF) and extruded rice flour (ERF) of genotypes IRGA-417 (G1), BRSPrimavera (G2) and CNA-8502 (G3).

\begin{tabular}{|c|c|c|c|c|c|}
\hline \multirow{2}{*}{ Property } & \multirow{2}{*}{ Treatment } & \multicolumn{3}{|c|}{ Genotype $^{2}$} & \multirow[b]{2}{*}{$\mathrm{TA}^{3}$} \\
\hline & & G1 & G2 & G3 & \\
\hline \multirow{2}{*}{$\mathrm{WAI}^{4}$} & NRF & $2.85 \pm 0.08$ & $2.64 \pm 0.06$ & $2.78 \pm 0.05$ & $2.76^{\mathrm{b}}$ \\
\hline & ERF & $10.23 \pm 0.02$ & $10.18 \pm 0.16$ & $10.56 \pm 0.36$ & $10.32^{\mathrm{a}}$ \\
\hline \multirow{2}{*}{$\mathrm{WSI}^{5}$} & NRF & $1.22 \pm 0.04^{\mathrm{Bb}}$ & $1.07 \pm 0.04^{\mathrm{Cb}}$ & $1.41 \pm 0.01^{\mathrm{Ab}}$ & - \\
\hline & ERF & $20.79 \pm 0.22^{\mathrm{Ca}}$ & $29.27 \pm 0.49^{\mathrm{Ba}}$ & $34.81 \pm 0.13^{\mathrm{Aa}}$ & - \\
\hline \multirow{2}{*}{$\mathrm{OAI}^{6}$} & NRF & $1.81 \pm 0.02$ & $1.67 \pm 0.05$ & $1.76 \pm 0.12$ & $1.75^{\mathrm{b}}$ \\
\hline & ERF & $1.97 \pm 0.13$ & $2.03 \pm 0.13$ & $2.02 \pm 0.08$ & $2.00^{\mathrm{a}}$ \\
\hline \multirow{2}{*}{$\mathrm{MAI}^{7}$} & NRF & $3.37 \pm 0.17$ & $3.00 \pm 0.06$ & $3.40 \pm 0.09$ & $3.26^{\mathrm{b}}$ \\
\hline & ERF & $20.26 \pm 1.03$ & $18.96 \pm 1.01$ & $22.02 \pm 0.65$ & $20.41^{\mathrm{a}}$ \\
\hline \multirow{2}{*}{$\mathrm{MSI}^{8}$} & NRF & $5.56 \pm 0.21$ & $5.01 \pm 0.44$ & $5.81 \pm 0.07$ & $5.46^{\mathrm{b}}$ \\
\hline & ERF & $60.66 \pm 1.83$ & $59.50 \pm 2.05$ & $65.29 \pm 1.35$ & $61.82^{\mathrm{a}}$ \\
\hline
\end{tabular}

${ }^{1}$ Mean values followed by standard deviations; ${ }^{2}$ different uppercase letters (same row) and lowercase (same column) differ significantly by the Tukey test at $5 \%$ probability; ${ }^{3} \mathrm{TA}$ : total average; ${ }^{4} \mathrm{WAI}$ : Water absorption index $\left(\mathrm{g}_{\text {gel }} \mathrm{g}_{\text {dry matter }}{ }^{-1}\right) ;{ }^{5}$ WSI: Water solubility index $\left(\mathrm{g} 100 \mathrm{~g}^{-1}\right),{ }^{6} \mathrm{OAI}$ : Oil absorption Index $\left.\mathrm{g}_{\text {precipitate }} \mathrm{g}_{\text {dry matter }}{ }^{-1}\right) ;{ }^{7}$ MAI: Milk absorption index $\left(\mathrm{g}_{\text {gel }} \mathrm{g}_{\text {dry matter }}{ }^{-1}\right) ;{ }^{8}$ MSI: Milk solubility index $\left(\mathrm{g} 100 \mathrm{~g}^{-1}\right)$.

Native starch virtually shows no cold water absorption, but pre-gelatinized starch has relatively high values, depending on the severity of the processing it has undergone (Linko, Colonna; Mercier, 1981). Bryant et al. (2001) evaluated the WAI of NRF of unknown genotype with moisture content of $12.4 \mathrm{~g} 100 \mathrm{~g}^{-1}$ before submitting it to the extrusion process and found WAI of $2.25 \mathrm{~g}_{\text {gel }} \mathrm{g}_{\text {dry }}$ ${ }^{-1}$, a value $18.5 \%$ lower than that found in this work.

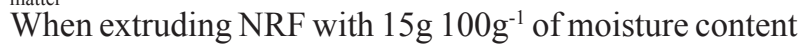
and temperature of $100^{\circ} \mathrm{C}$, the authors found an average WAI value of $4.48 \mathrm{~g}_{\text {gel }} \mathrm{g}_{\text {dry matter }}{ }^{-1}, 57 \%$ lower than the average values found in this study. Guha, Ali and Bhattacharya (2003) studied rice flours of cultivar IR-64 (28.6g 100 g-1 of amylose content) and cultivar Agoni Bora $\left(5{\left.\mathrm{~g} 100 \mathrm{~g}^{-1}\right)}^{-1}\right.$ found WAI levels of $2.6 \mathrm{~g}_{\text {gel }} \mathrm{g}_{\text {dry matter }}{ }^{-1}$ and $2.7 \mathrm{~g}_{\text {gel }} \mathrm{g}_{\text {dry matter }}{ }^{-1}$, similar to values found in this study. When extruding

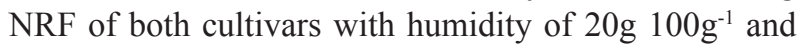
temperature of $100^{\circ} \mathrm{C}$, they found WAI of 5.0 and $5.1 \mathrm{~g}_{\text {gel }}$ $\mathrm{g}_{\text {dry matter }}{ }^{-1}$, while the values for ERF of genotypes of this studied under different extrusion conditions were greater than twice. High water absorption capacity is desirable for the preparation of soups, porridges and instant puddings (Torres et al., 1999), meat products, breads and cakes, which is important to help retaining moisture in the structure of products.

For MAI, the only significant effect was the industrial treatment. The average MAI of NRF was
$3.26 \mathrm{~g}_{\text {gel }} \mathrm{g}_{\text {dry matter }}{ }^{-1}$, while the value of extruded flours was $20.41 \mathrm{~g}_{\text {gel }} \mathrm{g}_{\text {dry matter }}{ }^{-1}$, an increase of 6.26 times. By comparing MAI with WAI values, there was an increase in values, indicating that there was greater milk absorption (98\%) in ERF compared to NRF in the three genotypes studied. MAI is important when seeking to develop products such as breakfast cereals or milk-based products such as instant baby foods, dairy desserts, cream cheese and sweets. In the case of extruded breakfast cereals, high MAI values are not interesting, since one of the characteristics of these products is the crispy texture even when soaked in milk.

\section{Water and milk solubility index}

There was a significant interaction $(\mathrm{P} \leq 0.05)$ between genotype and industrial treatment for WSI. Extrusion increased the WSI of ERF in relation to NRF around 2527 times in genotypes CNA-8502 and BRS-Primavera, respectively, and 17 times in genotype IRGA-417 (Table 3), which expands its applications, eg in instant products. During the extrusion process, there was macromolecular degradation of both amylose and amylopectin (dextrinization), leading to the formation of molecules of lower molecular weight and thus to products with greater water solubility (Ding et al., 2005), changes observed in the present study. The higher amylose content of rice flours after extrusion can be related to the breaking of $\alpha 1-6$ bonds, transforming part of 
amylopectin into amylose. The WSI was higher in ERF of genotype CNA-8502 and lower in genotype IRGA-417. The ERF of genotype CNA-8502 had the lowest amylose content

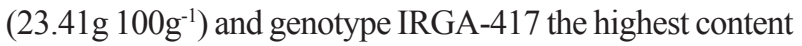

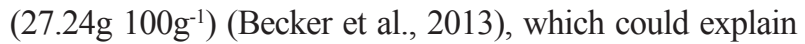
the different WSI values obtained in this study. Guha, Ali and Bhattacharya (2003) studied rice flours and found WSI

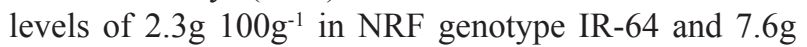
$100 \mathrm{~g}^{-1}$ in genotype Agoni Bora, and after extrusion, WSI values of 20.2 and $32.46 \mathrm{~g} 100 \mathrm{~g}^{-1}$ were found, respectively, which are similar to values obtained for ERF genotypes IRGA-417 and CNA-8502, respectively. Su (2007) extruded rice flour of genotype TNG-67 with $15 \mathrm{~g} 100 \mathrm{~g}^{-1}$ of moisture and temperature of $160^{\circ} \mathrm{C}$ and obtained WSI of $21.46{\mathrm{~g} 100 \mathrm{~g}^{-1}}^{-1}$ for ERF, close to value found for genotype IRGA-417 in the present study. No significant interaction $(\mathrm{P}>0.05)$ between genotype and industrial treatment was observed, but the milk solubility index (MSI) of raw flours was significantly affected after the extrusion process, increasing 11.3 times. Raw and extruded rice flours were, on average, $77.47 \%$ and $54.24 \%$, respectively, more soluble in milk than in water, indicating its application in the preparation of instant products such baby foods, desserts and milk-based products. Studies on absorption of milk are not found in the literature for comparison only on water absorption.

\section{Oil absorption index}

Only industrial treatment had significant effect $(\mathrm{P} \leq 0.05)$ on the OAI of flours. The extrusion process had little effect on the oil absorption of rice flour, as the average OAI value of extruded flours was only $12.5 \%$ higher than the average value determined for raw flours (Table 3). Bryant et al. (2001) studied the functional and digestive characteristics of extruded rice flour and found OAI values ranging from 0.8 to $1.2 \mathrm{~g}_{\text {precipitate }} \mathrm{g}_{\text {dry }}$ ${ }_{\text {matter }}^{-1}$ for ERF, which are lower than those found in this study. A higher content of gelatinized starch in the extruded flour would possibly increase the OAI value. The oil absorption is not desired in baked products, so for application of ERF to cover such foods should seek to reduce the gelatinization of starch during the extrusion process, using milder conditions of extrusion. The OAI is associated with the hydrophobic groups of extruded products and with the ability to maintain a certain amount of oil in its structure. In the extrusion process, starch granules undergo gelatinization and the hydrophilic / hydrophobic balance is changed, thus changing the oil absorption (Vernaza, Chang; Steel, 2009).

\section{CONCLUSIONS}

The extrusion process promoted changes in all physical and functional properties of rice flour, but only WSI and color parameters were influenced by genotype and by the industrial processing. Rice flours become darker, tending to a more reddish and yellow coloration after extrusion. Native and extruded rice flours of genotypes IRGA-417, BRS-Primavera and extruded rice flour of genotype CNA-8502 showed finer particles, while native flour of genotype CNA-8502 showed coarser particles. The extruded flours of IRGA-417 genotype obtained higher expansion and luminosity, and lower values of chroma $a^{*}$, chroma $b^{*}$ and water solubility, while the BRS-Primavera higher values of chroma $a^{*}$ and $\mathrm{b}^{*}$, and lower luminosity and expansion, and CAN-8502 higher water solubility and lower expansion and value of chroma a* The extrusion process led to flours with high water and milk absorption and solubility, low oil absorption and with potential for application in instant products, regardless of genotype.

\section{AKNOWLEDGMENTS}

To Capes for the Master's degree fellowship and financial support, the Fapeg for financial support and Embrapa Arroz e Feijão and Embrapa Amazônia Oriental for the partnership.

\section{REFERENCES}

ANDERSON, R.A. et al. Gelatinization of corn grits by roll-and extrusion cooking. Cereal Science Today. 14(1):4-12, 1969.

ASSOCIATION OF OFFICIAL ANALYTICAL CHEMISTS - AOAC. Official methods of analysis of the Association of Official Analytical Chemists. 18 ed. Washington: AOAC, 2010.

BASSINELLO, P.Z.; CASTRO, E.M. Arroz como alimento. Informe Agropecuário. 25(222):101-108, 2004.

BECKER, F.S. et al. Changes in chemical and viscoamylographic in flour from different rice genotypes subjected to extrusion. Ciência Rural. 43(10):19111917, 2013.

BORBA, A.M.; SARMENTO, S.B.S.; LEONEL, M. Efeito dos parâmetros de extrusão sobre as propriedades funcionais de extrusados da farinha de batata-doce.

Ciência e Tecnologia de Alimentos. 25(4):835-843, 2005. 
BRYANT, R.J. et al. Functional and digestive characteristics of extruded rice flour. Cereal Chemistry.78(2):131-137, 2001.

CHEYNE, A.; BARNES, J.; WILSON, D.I.

Extrusion behaviour of cohesive potato starch pastes:

I. Rheological characterisation. Journal of Food

Engineering. 66:1-12, 2005.

CLERICI, M.T.P.S.; EL-DASH, A.A. Technological properties of pre-gelatinized rice flour obtained by thermoplastic extrusion. Ciência e Agrotecnologia. 32(5):1543-1550, 2008.

COUTINHO, L.S. et al. Optimization of extrusion variables for the production of snacks from byproducts of rice and soybean. Ciência e Tecnologia de Alimentos. 33(4): 05-712, 2013.

DAY, L.; SWANSON, B.G. Functionality of proteinfortified extrudates. Comprehensive Reviews in Food Science and Food Safety. 12:546-564, 2013.

DING, Q.B. et al. The effect of extrusion conditions on the physicochemical properties and sensory characteristics of rice-based expanded snacks. Journal of Food Engineering. 66:283-289, 2005.

FELLOWS, P.J. Food processing technology: principles and practice. 3. ed. Boca Raton: CRC Press, 2009.

GUHA, M.; ALI, S.Z.; BHATTACHARYA, S. Screening of variables for extrusion of rice flour employing a Plackett-Burman design. Journal of Food Engineering. 57:135-144, 2003.

GUY, R. Raw materials for extrusion cooking. In: GUY, R. Extrusion Cooking. Boca Raton: Woodhead Publishing Limited, 2001. cap 2.

ILO, S.; BERGHOFER, E. Kinetics of colour changes during extrusion cooking of maize grits. Journal of Food Engineering. 39:73-80, 1999.
KADAN, R.S.; BRYANT, R.J.; PEPPERMAN, A.B. Functional properties of extruded rice flour. Journal of Food Science. 68(5):1669-1672, 2003.

LIMBERGER, V.M. et al. Modificação química e física do amido de quirera de arroz para aproveitamento na indústria de alimentos. Química Nova. 31(1):84-88, 2008.

LINKO, P.; COLONNA, P.; MERCIER, C. HTSTextrusion of cereal based materials. In: POMERANZ, Y. Advances in Cereal Sciences and Technology. Saint Paul: American Association of Cereal Chemists AACC, 4:145-235, 1981.

MENDONÇA, X. M. F. D. et al. Extrusión de harina mixta de amaranto integral y arroz: Parte 1. Caracterización físico-química. Alimentaria. 42(367):74-83, 2005.

NABESHIMA, E.H.; EL-DASH, A.A. Modificação química da farinha de arroz como alternativa para o aproveitamento dos subprodutos do beneficiamento do arroz. Boletim do Centro de Pesquisa de Processamento de Alimentos. 22(1):107-120, 2004.

SU, C.W. Effects of eggshell powder addition on the extrusion behaviour of rice. Journal of Food Engineering.79:607-612, 2007.

STATISTICAL ANALISYS SYSTEM - SAS.

Realease 8.1. Cary: The SAS Institute, 2003.

TORRES, R.L. et al. Comportamiento de variedades de arroz en la elaboración de pan sin gluten.

Archivos Latinoamericanos de Nutrición. 9(2):1625,1999 .

VERNAZA, M.G.; CHANG, Y.K; STEEL, C.J. Desenvolvimento de cereal matinal funcional orgânico enriquecido com farelo de maracujá: avaliação de propriedades tecnológicas. Brazilian Journal of Food Technology. 12:145-154, 2009. 